\title{
Types of Technological Entrepreneurs: a Study in a Large Emerging Economy
}

\author{
Lasso, Sarah Venturim; Mainardes, Emerson W.; Motoki, Fabio Y.S.
}

Published in:

Journal of the Knowledge Economy

Link to article, DOI:

10.1007/s13132-017-0470-4

Publication date:

2018

Document Version

Peer reviewed version

Link back to DTU Orbit

Citation $(A P A)$ :

Lasso, S. V., Mainardes, E. W., \& Motoki, F. Y. S. (2018). Types of Technological Entrepreneurs: a Study in a Large Emerging Economy. Journal of the Knowledge Economy, 9(2), 378-401. https://doi.org/10.1007/s13132017-0470-4

\section{General rights}

Copyright and moral rights for the publications made accessible in the public portal are retained by the authors and/or other copyright owners and it is a condition of accessing publications that users recognise and abide by the legal requirements associated with these rights.

- Users may download and print one copy of any publication from the public portal for the purpose of private study or research.

- You may not further distribute the material or use it for any profit-making activity or commercial gain

- You may freely distribute the URL identifying the publication in the public portal 


\title{
Types of technological entrepreneurs: a study in a large emerging economy
}

\author{
Sarah V. Lasso, Emerson W. Mainardes and Fabio Y. S. Motoki ${ }^{1}$
}

\begin{abstract}
This study identifies the profiles of technological entrepreneurs. Understanding what drives entrepreneurs can help policy design to incentivize entrepreneurship, support the development of better assistance for nascent businesses, and facilitate the matching between investors' and entrepreneurs' interests. Through the application of an online questionnaire, 325 Brazilian owners of technological startups answered their reasons to enterprise. The data was processed using Ward's hierarchical clustering algorithm, generating four distinct clusters. The first, financial success entrepreneurs, are concerned about financial outcomes of their startups. The new challenges group seeks self-realization, innovation, and independence by means of their enterprises. Leaders are driven by the will to lead and motivate others, relegating other factors. Finally, there are pessimistic entrepreneurs, who rank all reasons lower than other entrepreneurs. These results highlight that even within the class of technological entrepreneurs, from the same country, there are sizeable groups with different factors regarding reasons to enterprise, shedding some light on conflicting results in the entrepreneurial motivation literature.
\end{abstract}

Keywords: Entrepreneurship. Technological startups. Brazilian entrepreneurs. Profiles.

Accepted for publication on 23 February 2017.

Published version available at https://link.springer.com/article/10.1007/s13132-017-0470-4

DOI: $10.1007 / \mathrm{s} 13132-017-0470-4$

\footnotetext{
${ }^{1}$ Sarah V. Lasso (sarahvlasso@gmail.com) is a PhD student at the Technical University of Denmark and holds an MSc in Business Administration from FUCAPE Business School. Emerson W. Mainardes (emerson@fucape.br) is a professor at FUCAPE Business School and holds a PhD in Business Administration from Universidade da Beira Interior. Fabio Y. S. Motoki (fmotoki@ fucape.br) is a professor at FUCAPE Business School and holds a PhD in Accounting and Business Administration from FUCAPE Business School. Sarah and Emerson acknowledge financial support from FAPES (Fundação de Amparo à Pesquisa e Inovação do Espírito Santo).

Page 1 of 23
} 


\section{INTRODUCTION}

This study identifies the profiles of Brazilian technological entrepreneurs regarding their motivation to start a technological business. To understand entrepreneurship, one should start understanding he individual entrepreneur, who has the belief that his business will create value and engages on the activities to make it thrive (Gartner 1990; Dvir et al. 2010). A better understanding of what drives entrepreneurs can feed discussions about policy design to incentivize entrepreneurship with more effective, directed policies (Vivarelli 2013). This knowledge can also support the development of enhanced business environments for nascent business, increasing the likelihood of survival, and amplifying the economic benefits of entrepreneurship (Vivarelli 2013; Parker, 2005). Owens et al (2013) report that personality traits correlates with business success, while Quatraro and Vivarelli (2015) list several factors that relate to business survival, but none related to the motivations of the entrepreneur. Identifying the profiles of these entrepreneurs is the first step to understand how these groups interact with institutions, respond to incentives, and ultimately, how they succeed. Finally, uncovering these different groups and their motivations can facilitate the matching between investors' and entrepreneurs' interests. These gains in effectiveness can amplify the positive effects of entrepreneurship and boost the investment level in emerging countries (Shane 1996; Mueller and Thomas 2001; Bosma et al. 2012; Carayannis et al. 2006).

The study of the reasons to enterprise is an emerging area of research (Ferreira et al. 2016), and existing results sometimes are conflicting (Shane 1996; Muller and Thomas 2001; Dvir et al 2010; Barba-Sanchez and Atienza-Sahuquillo 2011). Most studies concentrate in the US or Europe (Mueller and Thomas 2001; Carter et al. 2003; Chen and Elston 2013; Autio et al. 2001). Ferreira et al. (2016) call for a greater internationalization of the field, reporting a concentration of studies in the US, UK, and Netherlands, with a heavy bias toward the American economy. Bjørnskov and Foss (2016) argue that many studies assume that there is a homogeneity in responses to institutional and policy differences between industries, business, countries and institutional settings, creating measurement error and at least partially explaining the lack of consensus. Quatraro and Vivarelli (2015) also advocate for the separation of the studies in advanced and developing countries, arguing that level of development influences entrepreneurship. This study answers this calls, reinforcing the importance of extending the research in emerging economies like Brazil, one of the top 10 largest economies of the world.

One should not underestimate the importance of entrepreneurs for the economy at large. King and Levine (1993) show how better financial systems fuel successful innovation and boosts economic growth. Galindo and Méndez (2014), using data from 13 countries, find that there is a feedback effect: economic activity promotes entrepreneurship and innovation, which in turn boosts economic activity. Stephens et al. (2013) report that, in lagging regions of the US, entrepreneurship and creativity are key in driving growth. These results highlight how entrepreneurs can feed virtuous cycles in the economy, creating progress in a sustainable way (Ferreira et al. 2016; Bjørnskov and Foss 2016).

The sample of the study comprises 325 Brazilian entrepreneurs who own a technological startup. These individuals answered an online questionnaire about their reasons to start a tech business, along with demographical data. Four clusters, reasonably well balanced in size, were formed using Ward's hierarchical clustering algorithm. One cluster are financial success entrepreneurs, concerned about financial outcomes of their startups. Another are the new challenges entrepreneurs, who seek self-realization, innovation, and independence by means of their enterprises. Leader entrepreneurs are driven by the will to lead and motivate others, relegating other factors. The last cluster, pessimistic entrepreneurs, rank all reasons lower than other entrepreneurs.

This research adds to the literature by documenting entrepreneurship reasons in the technological realm within an important emerging economy. These results may also help conciliating conflicting results in the existing literature, as even within the class of technological entrepreneurs, from the same country, there are sizeable groups with different factors regarding reasons to enterprise. These groups may also be used in

Page 2 of 23 
future research, verifying how these common traits relate with the institutional setting, incentives environment, and if they influence the likelihood of business success. This avenue of research can contribute to the discussion of more directed and effective policies aimed at driving entrepreneurship with a positive contribution to the local economy.

\section{LITERATURE REVIEW}

The field of research in entrepreneurship is an emergent and evolving one, and current efforts are heavily concentrated in the US, with UK and Netherlands well behind (Ferreira et al. 2016). This study answers the call from Ferreira et al. (2016) for more internationalization of the field, by bringing data from Brazil, a large developing economy. As Bjørnskov and Foss (2016) argue, many of the field's studies simply assume that there is a homogeneity between industries, business, countries and institutional settings, creating measurement error and at least partially explaining the lack of consensus observed in the literature (Shane 1996; Muller and Thomas 2001; Dvir et al. 2010; Barba-Sanchez and Atienza-Sahuquillo 2011). Moreover, Quatraro and Vivarelli (2015) advocate for the separation of the studies in advanced and developing countries. Quatraro and Vivarelli (2015) bring evidence showing that the level of development influences entrepreneurship, and it should be taken into account.

Entrepreneurship is also economically important, having both direct and indirect impacts on the economy as a whole. Galindo and Méndez (2014) study 13 countries and find that there is a feedback effect: economic activity promotes entrepreneurship and innovation, which in turn boosts economic activity. Entrepreneurship can also be a tool to tackle inequalities. For instance, Stephens et al. (2013) show that in lagging regions of the US entrepreneurship and creativity are key in driving growth. Taken together, these studies indicate how entrepreneurs can feed virtuous cycles in the economy, helping creating progress in a sustainable way (Ferreira et al 2016; Bjørnskov and Foss 2016).

\subsection{Entrepreneurs' characteristics}

Identifying types of entrepreneurs can be a useful endeavor, both for the academics and the economy. To have a real grasp of entrepreneurship one must start by understanding the entrepreneur, the one who believes that his or her business will create value, and engages in the activities to make it successful (Gartner, 1990; Dvir et al., 2010). Extant research suggests that motivational factors, related to the reasons to enterprise, affect startup growth (Baum et al. 2001).

Not everyone is fit to open a startup, identifying, exploring and pursuing opportunities to create new products and services, and those who do open one may not be able to manage it adequately (Jeng and Wells 2000). The success of a project may depend heavily on having a suitable entrepreneur (Jeng and Wells 2000), therefore the importance of documenting entrepreneurs' characteristics that drive the success of their enterprises. Brandstätter (2011) reinforces this view, documenting that entrepreneurs' personality traits, like achievement motivation, correlate with business creation and business success. Dvir et al. (2010) find that entrepreneurs tend to ventures that fit their personality. More than this, the way they manage their business is affected by these personality traits, potentially affecting the likelihood of success the enterprise (Dvir et al. 2010).

Some studies question whether entrepreneurship is intrinsically "good", or it may lead to undesired results under certain conditions. For instance, Vivarelli (2013) argues that there can be an excess of entries, with high rates of failures, that may not be economically interesting, since it does not lead to technological renewal nor to economic growth. Vivarelli (2013) calls for policies to discourage this unwanted behavior, and a first approach to tackle this problem is identifying which types of entrepreneurs there are in the economy. Shane (2009) argues that encouraging more people to become entrepreneurs can be counterproductive, and calls for better designed policy. Again, identifying the type of the entrepreneur seems a necessary step before taking any action. With such understanding, it may be possible to diminish

Page 3 of 23 
market churning, increasing the likelihood that high quality, high growth businesses will thrive and increasing the benefits of entrepreneurship (Vivarelli 2013; Shane 2009; Parker 2005).

There are few - if any - studies relating the reasons to enterprise to business survival. For instance, Quatraro and Vivarelli (2015) lists several factors related to the success of businesses, but none related to the motivations of the entrepreneurs. Owens et al. (2013) find that personality traits relate to small business success, but no motivation is studied. Adequate identification of different groups of entrepreneurs allows to study how each group interacts with institutions and responds to incentives. It is intuitive to think that if they have different motivations to start their businesses, probably they see these features differently. Creating a more customized approach for each group can lead to more effective policies, thus increasing the likelihood of success.

Another problem that may be addressed with the support of such information is better matching between investors' and entrepreneurs' interests. Understanding how these groups are motivated is key to investors being able to identify which ones fit their vision as venture capitalists. For example, Khosla Ventures' CEO, leader of one of the largest venture capital firms in the US, openly discusses the motivations he thinks are the right ones within the Silicon Valley vision (Khosla 2012). Additionally, Khosla Ventures also cite on their website, as part of the screening process, that " $(\mathrm{t}) \mathrm{he}$ focus is mostly on you, your goals and your technical team".

\subsection{Reasons for Entrepreneurship}

The creation of a startup is an intentional act involving several attempts to achieve the outcome. There are a series of obstacles for a startup to succeed, supporting the idea that they are not created by chance (Shaver et al., 2001; Koellinger et al., 2007). Autio et al. (2001) report that entrepreneurial intention has been measured in several studies in different ways. Some of these studies pose that intentions come first, and then entrepreneurs think of attitudes and perceptions towards entrepreneurship (Hayton and Cholakova, 2012).

Entrepreneurs have several reasons for opening a startup. Entrepreneurs evaluate a series of factors, like their motivation, commitment, and effort, that are relevant when thinking of opening a new venture (Dubini 1989; Barba-Sanchez and Atienza-Sahuquillo 2011). According to Dubini (1989), Carsrud and Brännback (2011) and Friedman and Aziz (2012), elements that motivate entrepreneurs fit into two factors. Intrinsic factors relate to recognition of the firm and colleagues. Extrinsic factors relate to status and the financial success. Chen and Elston (2013) also pose that factors can be classified into macro and micro levels, such as environment, personal characteristics, politics, culture, society, and market competition.

Several entrepreneurs report a need for achievement or self-realization, an intrinsic reason, as a major motivation to enterprise (Birley and Westhead, 1994). Taormina and Lao (2007) report that the desire to achieve is high among Chinese entrepreneurs. Collins et al. (2004), in a meta-analysis of the relation between achievement and entrepreneurial behavior, have shown that this achieve motivation is a strong predictor of entrepreneurship.

Some entrepreneurs report that starting a business is a way of fulfilling their need for financial success or economic safety, or even as a way of achieving a certain like style (Chen and Elston, 2013; Birley and Westhead, 1994). This is an extrinsic reason, as it is motivated by status and money, and a sizable portion of the entrepreneurs state it as an important motive to enterprise (Dubini, 1989; Carsrud and Brännback, 2011; Friedman and Aziz, 2012).

There are entrepreneurs who report the influence of other people as their motivation to enterprise. These people can be other entrepreneurs, famous people, colleagues, or family, and function as a role model for their actions (Dubini 1989; Shane et al. 1996; Bosma et al. 2012). This motivation is frequently cited by entrepreneurs. For instance, Bosma et al. (2012) report that a third of entrepreneurs cite an influential person as a key driver of their decision to enterprise. Taormina and Lao (2007) report it as a significant factor in explaining entrepreneurship. 
Innovation is often cited by entrepreneurs. Shane et al. (1991) report that entrepreneurs from Britain, New Zealand and Norway explicit a need to develop an idea for a product or business, and to stay at the frontier of technology development as important motives to open a business. Birley and Westhead (1994) find the same pattern in Great Britain. Shane (1996) documents that changes in technology are correlated with changes in rates of entrepreneurship in the US.

Many entrepreneurs report recognition as an important motivator to start a business. This factor is related to Maslow's fourth level need of esteem (Maslow, 1943). Birley and Westhead (1994) find that it is a major reason for UK entrepreneurs to start their enterprises. Jayawarna et al. (2013) report that the pursuit of prestige explains a sizeable portion of the motivation to enterprise in England. Shane et al. (1991) find similar results for Britain, New Zealand, and Norway.

Other people start their business seeking for independence. Dubini (1989) reports that the entrepreneur's flexibility in structuring his work, being in control of his time, choosing his collaborators and his work's location as a relevant motivator. More recently, Jayawarna et al. (2013) reports flexibility as an important factor in explaining entrepreneur motivation in England, being second only to achievement among seven factors.

These six factors, self-realization, financial success, roles, innovation, recognition and independence, are summarized by Carter et al. (2003). For Carter et al. (2003), self-realization represents what the individual is able to perform. The financial success factor relates to financial gains. Roles reflect the familiar influences that can motivate an individual to undertake an enterprise, or if the person already is successful in business. Innovation concerns the creation of new products and services, and reflects an individual linked to the technology market. Recognition means that the desire for the individual to be recognized by those important for him. The last factor, independence, means flexibility and freedom of the individual in the workplace. Table 1 provides a summary of several papers that delve into these factors. In their study, Carter et al. (2003) conduct a comparison between entrepreneurs and not entrepreneurs and find that these six factors are able to distinguish the two groups, and represent $68 \%$ of the observed variance. This study builds on Carter et al. (2003) factors to classify entrepreneurs into groups. This is detailed in the next section.

Table 1: Factors that lead entrepreneurs to open technological startups

\begin{tabular}{|l|l|}
\hline Factors & Authors \\
\hline $\begin{array}{l}\text { Self- } \\
\text { realization }\end{array}$ & $\begin{array}{l}\text { Aziz and Friedman (2012), Birley and Westhead (1994), Carsrud and Brännback } \\
(2011), \text { Carter et al., (2003), Collins et al. (2004), Dubini (1989), Taormina and Lao } \\
(2007)\end{array}$ \\
\hline $\begin{array}{l}\text { Financial } \\
\text { success }\end{array}$ & $\begin{array}{l}\text { Aziz and Friedman (2012), Birley and Westhead (1994), Carsrud and Brännback } \\
(2011), \text { Carter et al. (2003), Chen and Elston (2013), Dubini (1989) }\end{array}$ \\
\hline Roles & $\begin{array}{l}\text { Bosma et al., (2012), Carter et al., (2003), Dubini (1989), Shane et al. (2003), } \\
\text { Taormina and Lao (2007) }\end{array}$ \\
\hline Innovation & $\begin{array}{l}\text { Birley and Westhead (1994), Carter et al., (2003), Mueller and Thomas (2001), } \\
\text { Shane et al. (1991), Shane (1996) }\end{array}$ \\
\hline Recognition & $\begin{array}{l}\text { Birley and Westhead (1994), Carsrud and Brännback (2011), Carter et al., (2003), } \\
\text { Dubini (1989), Friedman and Aziz (2012), Jayawarna et al. (2013), Maslow (1943), } \\
\text { Shane et al. (1991) }\end{array}$ \\
\hline Independence & Carter et al., (2003), Chen and Elston (2013), Dubini (1989), Jayawarna et al. (2013) \\
\hline
\end{tabular}

Source: Authors.

\section{METHODOLOGY}

This research uses a quantitative approach based on descriptive characteristics from a cross-sectional dataset built with primary and subjective data. The population for this study are the Brazilian founders and

Page 5 of 23 
owners of nascent technological startups. In the lack of reliable data in Brazil about startups, the Brazilian Association of Startups speculates that there may be around 10,000 technology-based business in the country (Associação Brasileira de Startups 2013). A questionnaire was sent to all of ABStartups (Brazilian Startups Association) associates, around 300 companies. It was also distributed using Facebook groups and profiles related to startups, Linkedin, and entrepreneurship events and courses.

Convenience sampling yielded answers from 325 Brazilian entrepreneurs. The questionnaire has 28 items. One is a control question, which asks if the respondent owns a startup. Negative answers led to the dropping of the observation. Five questions are demographical: gender, age, education, startup market and working experience. The remaining 22 statements are based on Carter et al., (2003), and query respondents on the importance of reasons for entrepreneurship through technological startups. These 22 statements fit into one of six factors: self-realization (six statements), financial success (five statements), roles (three statements), innovation (three statements), recognition (three statements) and independence (two statements), as Table 2 details.

Table 2: Factors and variables

\begin{tabular}{|l|l|}
\hline Factor & Variable name and reference \\
\hline \multirow{5}{*}{ Self- realization } & $\begin{array}{l}\text { Self-accomplishment (AR1) } \\
\text { New challenges (AR2) } \\
\text { Learn as a person (AR3) } \\
\text { Lead and motivate others (AR4) } \\
\text { To have power to influence a company (AR5) }\end{array}$ \\
\hline & $\begin{array}{l}\text { Financial success (FIN1) } \\
\text { Financial independence (FIN2) } \\
\text { Greater personal income (FIN3) } \\
\text { Financial security (FIN4) } \\
\text { Build wealth (FIN5) }\end{array}$ \\
\hline Independence & $\begin{array}{l}\text { Flexibility (IND1) } \\
\text { Freedom for work methods (IND2) }\end{array}$ \\
\hline Innovation & $\begin{array}{l}\text { Create and sell new products (INOV1) } \\
\text { Follow technological innovations (INOV2) } \\
\text { Many products ideas (INOV3) } \\
\text { Market opportunity (INOV4) }\end{array}$ \\
\hline \multirow{2}{*}{ Roles } & $\begin{array}{l}\text { For children to inherit (PA1) } \\
\text { Family tradition (PA2) } \\
\text { Follow examples (PA3) }\end{array}$ \\
\hline \multirow{2}{*}{ Recognition } & $\begin{array}{l}\text { Importance in market -society (REC1) } \\
\text { Society's recognition (REC2) } \\
\text { Friends' respect (REC3) }\end{array}$ \\
\hline
\end{tabular}

To create the groups of entrepreneurs, we rely on a clustering algorithm. As Hair et al (2013) point, cluster analysis forms groups of homogeneous objects using an objective method. The goal is to maximize intracluster homogeneity, while maximizing between-clusters heterogeneity. In this study, the objects are entrepreneurs. In this fashion, the analysis forms groups so that an entrepreneur from a given cluster is more similar to another entrepreneur from the same cluster than to any other entrepreneur from any other cluster. More specifically, we run the answers through a hierarchical cluster analysis using Ward's method, paired with a squared Euclidean distance metric. This method minimizes intra-group variation, while tending to produce similar-sized clusters (Hair et al. 2013). Next section presents the sample and the clusters formed. 


\section{DATA ANALYSIS}

\subsection{Sample Demographics}

Table 3 presents the demographics of the sample. The majority of the respondents are on the younger age ranges covering 18-34 years old respondents. In particular, they concentrate on the 25-28 stratum, with the 18-24 and 29-34 strata following practically tied. The over 42 years-old stratum is the smallest, indicating a relatively young sample.

Regarding gender, the vast majority is of men. Most of the respondents also have at least a bachelor's degree, with a sizeable portion holding graduate titles, showing that the respondents are academically qualified.

Table 3: Sample demographics

\begin{tabular}{|c|c|c|c|}
\hline Variable & Class & $\mathrm{N}$ & $\%$ \\
\hline \multirow{5}{*}{ Age } & $18-24$ & 80 & 24.61 \\
\hline & $25-28$ & 105 & 32.30 \\
\hline & $29-34$ & 75 & 23.07 \\
\hline & $35-42$ & 42 & 12.93 \\
\hline & over 42 & 23 & 7.07 \\
\hline \multirow{2}{*}{ Gender } & Female & 28 & 8.61 \\
\hline & Male & 297 & 91.38 \\
\hline \multirow{4}{*}{ Education } & High school & 10 & 3.07 \\
\hline & Bachelor & 205 & 63.07 \\
\hline & Other graduate studies & 60 & 18.46 \\
\hline & Master/Doctorate/PhD & 50 & 15.38 \\
\hline \multirow{9}{*}{ Startup market } & Mobile app & 42 & 12.92 \\
\hline & E-commerce & 31 & 9.53 \\
\hline & Education & 21 & 6.46 \\
\hline & Games & 11 & 3.38 \\
\hline & Artificial intelligence (robotics) & 6 & 1.84 \\
\hline & Sustainable products & 9 & 2.76 \\
\hline & Health & 18 & 5.53 \\
\hline & Services & 99 & 30.46 \\
\hline & Others & 88 & 27.07 \\
\hline \multirow{3}{*}{ Working experience } & & 117 & 36 \\
\hline & I never had startup experience but I had worked in companies & 169 & 52 \\
\hline & I don't have experience & 39 & 12 \\
\hline
\end{tabular}

Brazilian entrepreneurs operate mostly in the Services industry. Only a minority operates within the AI industry, possibly due to the highly technical nature of the field. Most of the respondents have some kind of work experience and previous experience in a non-startup firm. Our sample exhibits differences when compared to the demographics of other international studies, in particular age and education, but they are attributable to differences in target entrepreneurship areas (Cowling 2000; Chen and Elston 2013; Carter et al. 2003).

\subsection{Cluster analysis}

Ward's hierarchical clustering algorithm formed 4 clusters. Table 4 has the details. The first cluster is named "Financial success entrepreneurs". This cluster has an overwhelming majority of men and the highest proportion of older people. All answers from the Financial Success factor from this cluster present a higher mean when compared to other entrepreneurs, indicating that this group focuses on financial reasons 
more than others. Chen and Elston (2013), Dubini (1989), and Friedman and Aziz (2012) also identify similar financially-driven groups in other settings.

The second cluster is comprised of "New challenger entrepreneurs". It is the largest cluster of all, with a majority of young people up to 28 years-old. These entrepreneurs are highly qualified, with a third holding some kind of graduate degree, while being inexperienced. In this cluster, all Self-Realization, Independence, and Innovation variables present statistically significant higher means than the other entrepreneurs, indicating that these two factors matter the most for them.

The third cluster, "Leader entrepreneurs", has the highest proportion of middle-aged people (35-42 yearsold) and the highest proportion of experienced entrepreneurs. People in this group tend to rank factors lower than others, while their relative importance for recognition is about the same with no different means. Since this group shows a larger proportion of experienced people, this could signal that it has a more balanced or grounded view of their reasons to enterprise.

\section{Table 4: Clusters found}

\begin{tabular}{|c|c|c|}
\hline Cluster & Characteristics & $\begin{array}{l}\text { Statistically different } \\
\text { means }\end{array}$ \\
\hline \multirow{6}{*}{$\begin{array}{l}\text { Financial success } \\
\text { entrepreneurs } \\
\text { (cluster 1) }\end{array}$} & \multirow{6}{*}{$\begin{array}{l}78 \text { respondents. } \\
\text { Lowest proportion of women }(3.84 \%) \text {. } \\
\text { Highest proportion of entrepreneurs over } 42 \text { years } \\
\text { old }(12.82 \%) \\
\text { Highest proportion of entrepreneurs in the } \\
\text { sustainable products area }(5 \%) \text {. }\end{array}$} & Self-realization: $1 / 5$ \\
\hline & & Financial: $5 / 5$ \\
\hline & & Independence: $0 / 2$ \\
\hline & & Innovation: $1 / 4$ \\
\hline & & Roles: $3 / 3$ \\
\hline & & Recognition: $1 / 3$ \\
\hline \multirow{6}{*}{$\begin{array}{l}\text { New challenges } \\
\text { entrepreneurs } \\
\text { (cluster } 2 \text { ) }\end{array}$} & \multirow{6}{*}{$\begin{array}{l}96 \text { respondents. Largest cluster. } \\
\text { Highest proportion of young entrepreneurs (from } 18 \\
\text { to } 28 \text { years old - 69\%). } \\
\text { Highest proportion of entrepreneurs with } \\
\text { specialization, master and PhD }(33 \%) \text {. } \\
\text { Highest proportion on e-commerce and games } \\
(17 \%) \text {. } \\
\text { Highest proportion of entrepreneurs with no startup } \\
\text { experience and no experience at all }(92 \%) \text {. }\end{array}$} & Self-realization: $5 / 5$ \\
\hline & & Financial: $3 / 5$ \\
\hline & & Independence: $2 / 2$ \\
\hline & & Innovation: 4/4 \\
\hline & & Roles: 2/3 (-, +) \\
\hline & & Recognition: $2 / 3$ \\
\hline \multirow{6}{*}{$\begin{array}{l}\text { Leader entrepreneurs } \\
\text { (cluster 3) }\end{array}$} & \multirow{6}{*}{$\begin{array}{l}92 \text { respondents. } \\
\text { Highest proportion of } 35 \text { to over } 42 \text { years old } \\
\text { entrepreneurs }(20 \%) \text {. } \\
\text { Highest proportion of entrepreneurs on mobile apps } \\
(14 \%) \text {. } \\
\text { Lowest proportion of entrepreneurs with High school } \\
\text { education }(1.08 \%) \text {. } \\
\text { Highest proportion of entrepreneurs in the service } \\
\text { market (34\%). } \\
\text { Highest proportion of entrepreneurs with startup } \\
\text { experience }(15 \%) \text {. }\end{array}$} & Self-realization: $2 / 5(-,+)$ \\
\hline & & Financial: 4/5 (-) \\
\hline & & Independence: $2 / 2(-)$ \\
\hline & & Innovation: 3/4 (-) \\
\hline & & Roles: 2/3 (-) \\
\hline & & Recognition: $0 / 3$ \\
\hline \multirow{6}{*}{$\begin{array}{l}\text { Pessimistic } \\
\text { entrepreneurs } \\
\text { (cluster 4) }\end{array}$} & \multirow{6}{*}{$\begin{array}{l}59 \text { respondents. Smallest cluster. } \\
\text { Highest proportion of women }(11 \%) \text {. }\end{array}$} & Self-realization: 5/5 (-) \\
\hline & & Financial: $5 / 5(-)$ \\
\hline & & Independence: $2 / 2(-)$ \\
\hline & & Innovation: 4/4 (-) \\
\hline & & Roles: 3/3 (-) \\
\hline & & Recognition: 3/3 (-) \\
\hline
\end{tabular}


Notes: The third column shows how many of the variables within a given factor have a different mean, and the total number of variables within a factor, e.g., $4 / 6$ denotes that 4 out of 6 variables have statistically significant differences in means. All differences in means are positive [Mean(Cluster) - Mean(Rest) $>0$ ], unless noted otherwise. $(-,+)$ denotes mixed results, with some means lower, other higher, and (-) denotes all means are lower.

The fourth and last cluster are the "Pessimistic entrepreneurs". People in this group consistently attribute less importance to all variables from all factors than others. It is the smallest cluster, and has the largest proportion of women.

This general characterization provides a brief overview of each cluster, highlighting between-clusters differences. Now we turn to the specificities of each cluster.

\subsubsection{Financial Success Entrepreneurs}

Table 5 shows the differences in means between the Financial Success cluster's entrepreneurs answers and other entrepreneurs.

Table 5: Financial Success cluster vs. other entrepreneurs - differences in means

\begin{tabular}{|c|c|c|c|c|c|c|c|}
\hline Variables & $\begin{array}{l}\text { Diff in } \\
\text { Means }\end{array}$ & $\begin{array}{l}\text { Equal } \\
\text { variances }\end{array}$ & $\begin{array}{l}\text { Std. } \\
\text { Error }\end{array}$ & $\mathrm{t}$ & Sig. & Lower & Upper \\
\hline \multirow{2}{*}{$\begin{array}{l}\text { To have power to } \\
\text { influence a company } \\
\text { (AR5) }\end{array}$} & \multirow{2}{*}{0.6734} & Yes & 0.1732 & 3.8880 & 0.0000 & 0.3327 & 1.0141 \\
\hline & & No & 0.1665 & 4.0440 & 0.0000 & 0.3442 & 1.0027 \\
\hline \multirow{2}{*}{ Financial success (FIN1) } & \multirow{2}{*}{0.6471} & Yes & 0.1274 & 5.0810 & 0.0000 & 0.3965 & 0.8977 \\
\hline & & No & 0.1111 & 5.8240 & 0.0000 & 0.4277 & 0.8665 \\
\hline \multirow{2}{*}{$\begin{array}{l}\text { Financial independence } \\
\text { (FIN2) }\end{array}$} & \multirow{2}{*}{1.0095} & Yes & 0.1529 & 6.6040 & 0.0000 & 0.7087 & 1.3102 \\
\hline & & No & 0.1287 & 7.8430 & 0.0000 & 0.7555 & 1.2634 \\
\hline \multirow{2}{*}{$\begin{array}{l}\text { Greater personal income } \\
\text { (FIN3) }\end{array}$} & \multirow{2}{*}{1.2213} & Yes & 0.1505 & 8.1160 & 0.0000 & 0.9253 & 1.5174 \\
\hline & & No & 0.1275 & 9.5820 & 0.0000 & 0.9698 & 1.4729 \\
\hline \multirow{2}{*}{ Financial security (FIN4) } & \multirow{2}{*}{1.8003} & Yes & 0.1379 & 13.0580 & 0.0000 & 1.5291 & 2.0715 \\
\hline & & No & 0.1446 & 12.4550 & 0.0000 & 1.5141 & 2.0865 \\
\hline \multirow{2}{*}{ Build wealth (FIN5) } & \multirow{2}{*}{1.5648} & Yes & 0.1535 & 10.1950 & 0.0000 & 1.2628 & 1.8667 \\
\hline & & No & 0.1339 & 11.6890 & 0.0000 & 1.3005 & 1.8291 \\
\hline \multirow{2}{*}{$\begin{array}{l}\text { Market opportunity } \\
\text { (INOV4) }\end{array}$} & \multirow{2}{*}{0.3475} & Yes & 0.1195 & 2.9070 & 0.0040 & 0.1123 & 0.5827 \\
\hline & & No & 0.1073 & 3.2400 & 0.0010 & 0.1356 & 0.5594 \\
\hline \multirow{2}{*}{ For children inherit (PA1) } & \multirow{2}{*}{1.3104} & Yes & 0.1448 & 9.0530 & 0.0000 & 1.0256 & 1.5952 \\
\hline & & No & 0.1643 & 7.9780 & 0.0000 & 0.9848 & 1.6360 \\
\hline \multirow{2}{*}{ Family tradition (PA2) } & \multirow{2}{*}{0.6532} & Yes & 0.1104 & 5.9180 & 0.0000 & 0.4361 & 0.8703 \\
\hline & & No & 0.1425 & 4.5830 & 0.0000 & 0.3702 & 0.9361 \\
\hline \multirow{2}{*}{ Follow examples (PA3) } & \multirow{2}{*}{0.4615} & Yes & 0.1657 & 2.7850 & 0.0060 & 0.1356 & 0.7875 \\
\hline & & No & 0.1623 & 2.8440 & 0.0050 & 0.1406 & 0.7825 \\
\hline \multirow{2}{*}{ Friend's respect (REC3) } & \multirow{2}{*}{0.2740} & Yes & 0.0806 & 3.3990 & 0.0010 & 0.1154 & 0.4325 \\
\hline & & No & 0.0942 & 2.9080 & 0.0040 & 0.0872 & 0.4607 \\
\hline
\end{tabular}

Notes: Diff in Means is Mean(Financial Success, N=78) - Mean(Other entrepreneurs, N=247). Equal variances indicates if the difference in means test assumes equal or unequal variances. Std. Error, $t$, Sig, Lower and Upper are the standard error of the difference in means, $t$ statistic of the test, p-value of the test, and the lower and upper bounds of a $95 \%$ confidence interval for the difference in means, respectively. AR is self-realization, FIN is Financial Success, INOV is Innovation, PA is Roles and REC is Recognition.

Only one variable from the Self-Realization (AR) factor exhibits a different mean. This cluster ranks the power to influence a company higher than other entrepreneurs. This result is somewhat intuitive, people who have high regard for financial outcomes may tend to also value power (Winarick 2010).

Page 9 of 23 
Within the Financial Success factor, all of the five variables show positive and significant differences in means, with two being close to one, and two being clearly above one, even considering the $95 \%$ confidence interval. It indicates that this cluster holds financial outcomes more dearly than their counterparts. It extends the cross-country differences regarding this factor suggested by existing literature. For instance, Yueh (2009) find that Chinese entrepreneurs show strong financial reasons to open a new venture, whereas Robert (1989) reports that MIT students think that financial gains are of secondary importance. In this case, the result stresses that these differences also exist within a single country.

This cluster's entrepreneurs rank market opportunity, a variable of the Innovation factor, more strongly than their peers. Del Junco and Brás-dos-Santos (2009) show such pattern for Spain, Germany, and Italy, who cite seizing opportunity as an important reason to create a new business. All in all, this cluster resembles somewhat these countries, as seizing opportunity, ambition - which relates to the Financial Success factor - and independence appear as the main reasons in all three.

Another factor in this cluster that shows significant positive differences for all variables is Roles (PA). For these entrepreneurs, Roles is an important determinant to start an enterprise. This group differs markedly from the ones studied by Dubini (1989), Shane et al. (1996), and Bosma et al. (2012), as these papers find little influence of role models. Finally, this cluster's entrepreneurs also weight friend's respect more importantly than others. It may be related to the Financial Success factors, as achieving positive financial results could produce more friends' respect.

This cluster has two marked characteristics, valuing Financial Success and Roles more strongly than others. However, the differences of Financial Success' variables seem to be stronger, as all of them are close or even higher than one, while for Roles the differences are not so great. Thus, Financial Success defines its main characteristic and lends its name to the cluster.

\subsubsection{New Challenges Entrepreneurs}

Table 6 show the differences in means for the next cluster, New Challenges Entrepreneurs. This group shows differences in all six factors. However, three factors deserve highlight: all five of the SelfRealization, all two of the Independence, and all four of the Innovation variables show positive differences in means in relation to other entrepreneurs.

Table 6: New Challenges cluster vs. other entrepreneurs - differences in means

\begin{tabular}{llllllll}
\hline \multirow{2}{*}{ Variables } & $\begin{array}{l}\text { Diff in } \\
\text { Means }\end{array}$ & $\begin{array}{l}\text { Equal } \\
\text { variances }\end{array}$ & $\begin{array}{l}\text { Std. } \\
\text { Error }\end{array}$ & t & Sig. & Lower & Upper \\
\hline Self-accomplishment & \multirow{2}{*}{0.5417} & Yes & 4.3180 & 0.0000 & 0.1255 & 0.2949 & 0.7885 \\
(AR1) & & No & 5.1850 & 0.0000 & 0.1045 & 0.3360 & 0.7473 \\
& \multirow{2}{*}{ New challenges (AR2) } & \multirow{2}{*}{ Yes } & 6.3110 & 0.0000 & 0.1167 & 0.5067 & 0.9657 \\
& & No & 8.0540 & 0.0000 & 0.0914 & 0.5564 & 0.9161 \\
Learn as a person (AR3) & \multirow{2}{*}{0.7188} & Yes & 6.2020 & 0.0000 & 0.1159 & 0.4908 & 0.9467 \\
& & No & 7.8140 & 0.0000 & 0.0920 & 0.5377 & 0.8998 \\
Lead and motivate others & \multirow{2}{*}{0.9440} & Yes & 6.5280 & 0.0000 & 0.1446 & 0.6595 & 1.2285 \\
(AR4) & & No & 7.7270 & 0.0000 & 0.1222 & 0.7035 & 1.1845 \\
To have power to & \multirow{2}{*}{1.0527} & Yes & 6.7830 & 0.0000 & 0.1552 & 0.7474 & 1.3580 \\
influence a company & & No & 7.7080 & 0.0000 & 0.1366 & 0.7837 & 1.3217 \\
(AR5) & \multirow{2}{*}{0.3830} & Yes & 3.1380 & 0.0020 & 0.1221 & 0.1428 & 0.6231 \\
Financial success (FIN1) & & No & 3.5120 & 0.0010 & 0.1090 & 0.1681 & 0.5978 \\
& & Yes & 4.5670 & 0.0000 & 0.1478 & 0.3842 & 0.9656 \\
Financial independence & \multirow{2}{*}{0.6749} & No & 5.3660 & 0.0000 & 0.1258 & 0.4272 & 0.9225 \\
(FIN2) & & Yes & 4.1010 & 0.0000 & 0.1507 & 0.3215 & 0.9144 \\
Greater personal income & \multirow{2}{*}{0.6180} & No & 4.5120 & 0.0000 & 0.1370 & 0.3481 & 0.8878 \\
\hline (FIN3) & & & & & & & \\
\hline
\end{tabular}

Page 10 of 23 


\begin{tabular}{llllllll}
\hline \multirow{2}{*}{ Flexibility (IND1) } & \multirow{2}{*}{0.8744} & Yes & 5.4160 & 0.0000 & 0.1614 & 0.5568 & 1.1920 \\
& & No & 5.9030 & 0.0000 & 0.1481 & 0.5824 & 1.1663 \\
Freedom for work & \multirow{2}{*}{0.9588} & Yes & 6.9070 & 0.0000 & 0.1388 & 0.6857 & 1.2319 \\
methods (IND2) & & No & 8.6510 & 0.0000 & 0.1108 & 0.7407 & 1.1769 \\
\hline Create and sell new & \multirow{2}{*}{0.5244} & Yes & 3.5390 & 0.0000 & 0.1482 & 0.2329 & 0.8159 \\
products (INOV1) & & No & 3.6760 & 0.0000 & 0.1427 & 0.2430 & 0.8057 \\
Follow technological & \multirow{2}{*}{0.8438} & Yes & 5.5850 & 0.0000 & 0.1511 & 0.5466 & 1.1410 \\
innovation(INOV2) & & No & 6.2800 & 0.0000 & 0.1344 & 0.5791 & 1.1085 \\
Many products ideas & \multirow{2}{*}{0.5184} & Yes & 3.5540 & 0.0000 & 0.1459 & 0.2314 & 0.8053 \\
(INOV3) & & No & 3.7760 & 0.0000 & 0.1373 & 0.2477 & 0.7890 \\
Market opportunity & \multirow{2}{*}{0.3623} & Yes & 3.2480 & 0.0010 & 0.1116 & 0.1429 & 0.5818 \\
(INOV4) & & No & 3.8730 & 0.0000 & 0.0936 & 0.1781 & 0.5465 \\
\hline \multirow{2}{*}{$\begin{array}{l}\text { For children to inherit } \\
\text { (PA1) }\end{array}$} & \multirow{2}{*}{0.2856} & Yes & -1.8930 & 0.0490 & 0.1509 & -0.5824 & 0.0113 \\
& & No & -2.1370 & 0.0340 & 0.1336 & -0.5488 & -0.0224 \\
Follow examples (PA3) & \multirow{2}{*}{1.1165} & Yes & 7.7450 & 0.0000 & 0.1442 & 0.8329 & 1.4000 \\
& & No & 8.4390 & 0.0000 & 0.1323 & 0.8557 & 1.3772 \\
\hline Importance in market - & \multirow{2}{*}{0.4498} & Yes & 3.0720 & 0.0020 & 0.1465 & 0.1617 & 0.7379 \\
society (REC1) & & No & 3.3400 & 0.0010 & 0.1347 & 0.1844 & 0.7153 \\
Society's recognition & \multirow{2}{*}{0.6867} & Yes & 4.4500 & 0.0000 & 0.1543 & 0.3831 & 0.9903 \\
(REC2) & No & 4.6580 & 0.0000 & 0.1474 & 0.3960 & 0.9774 \\
\hline
\end{tabular}

Notes: Diff in Means is Mean(New Challenges, $\mathrm{N}=96$ ) - Mean(Other entrepreneurs, $\mathrm{N}=229)$. Equal variances indicates if the difference in means test assumes equal or unequal variances. Std. Error, $t$, Sig, Lower and Upper are the standard error of the difference in means, $t$ statistic of the test, $p$-value of the test, and the lower and upper bounds of a $95 \%$ confidence interval for the difference in means, respectively. AR is self-realization, FIN is Financial Success, IND is Independence, INOV is Innovation, PA is Roles and REC is Recognition.

This is the largest cluster, with 96 entrepreneurs, or almost $30 \%$ of the sample. It is dubbed New Challenges because of the three factors that show positive differences in means for all of their variables. Thus, entrepreneurs from this cluster rank high facing challenges by working on new products using their own methods.

The first factor that shows positive and significant differences for all of its variables is Self-Realization. Entrepreneurs from this cluster exacerbate several well-documented traits for entrepreneurs around the world. Self-accomplishment seems to be inherent to entrepreneurs (Carsrud and Brännback 2011), and seems to be even stronger for entrepreneurs from this cluster. These entrepreneurs are also more keen about facing challenges than others, another trait also reported for entrepreneurs (Carter et al. 1996; Liao et al. 2005; Buijs 2008). This cluster's entrepreneurs rank higher than their peers learning as a person and lead and motivate others, characteristics reported by Gupta and Fernandez (2009), who affirm that entrepreneurs are curious, and Dubini (1989), Shane et al. (2003) and Bosma et al. (2012), who show that entrepreneurs want to motivate and influence others. Finally, they show the need for power more than others, a characteristic documented by Roberts (1989).

The second factor for which all of its variables show positive and significant differences in means is Independence. These entrepreneurs value flexibility and freedom to implement their own work methods higher than others. Thus, they also exacerbate two traits already found in other settings, by Del Junco and Brás-dos-Santos (2009) who find that Spanish, German and Italian entrepreneurs frequently cite having independence as a reason to open a business, and by Carter et al. (2003), who document the freedom motivation.

The third and last factor with significant and positive differences in means for all of its variables is Innovation. This cluster connects directly with the top factor loadings found by Carter et al. (2003) for their innovation factor: to be at the frontier of technology and to develop a product.

Page 11 of 23 
There is some financial motivation beyond those three markedly different factors. Three out of the five variables show significant, positive differences: these entrepreneurs are seeking more income and more financial independence, i.e., financial security (Chen and Elston 2013). However, they do not see building a legacy for children as important, as the negative and significant difference in means shows. Finally, this group is enterprising to follow examples, and also expects recognition from the society.

All in all, this could be the stereotypical entrepreneur group. This cluster is the largest one, comprised of young people, with little or no startup experience. They seek self-realization, love independence, want to innovate, but also look for some financial security and recognition from the society (Dubini 1989; Friedman and Aziz 2012; Carsrud and Brännback 2011; Del Junco and Brás-dos-Santos 2009; Carter et al. 2003; Chen and Elston 2013).

\subsubsection{Leader Entrepreneurs}

Table 7 shows the significant differences for the so-called Leaders cluster. In general, entrepreneurs from this group show means that are lower than the ones from other entrepreneurs. However, one variable shows a positive and significant difference: the reason to lead and motivate others appears as more important for these people than for other entrepreneurs. Hence, the name of the cluster.

Table 7: Leaders cluster vs. other entrepreneurs - differences in means

\begin{tabular}{|c|c|c|c|c|c|c|c|}
\hline Variables & $\begin{array}{l}\text { Diff in } \\
\text { Means }\end{array}$ & $\begin{array}{c}\text { Equal } \\
\text { variances }\end{array}$ & $\begin{array}{l}\text { Std. } \\
\text { Error }\end{array}$ & $\mathbf{t}$ & Sig. & Lower & Upper \\
\hline \multirow{2}{*}{$\begin{array}{l}\text { Lead and motivate others } \\
\text { (AR4) }\end{array}$} & \multirow{2}{*}{0.4155} & Yes & 2.6960 & 0.0070 & 0.1541 & 0.1123 & 0.7186 \\
\hline & & No & 3.1880 & 0.0020 & 0.1303 & 0.1588 & 0.6722 \\
\hline \multirow{2}{*}{$\begin{array}{l}\text { To have power to influence a } \\
\text { company (AR5) }\end{array}$} & \multirow{2}{*}{-0.5756} & Yes & -3.4910 & 0.0010 & 0.1649 & -0.9000 & -0.2512 \\
\hline & & No & -3.6290 & 0.0000 & 0.1586 & -0.8886 & -0.2626 \\
\hline \multirow{2}{*}{$\begin{array}{l}\text { Financial independence } \\
\text { (FIN2) }\end{array}$} & \multirow{2}{*}{-0.4713} & Yes & -3.0980 & 0.0020 & 0.1522 & -0.7706 & -0.1720 \\
\hline & & No & -3.1730 & 0.0020 & 0.1485 & -0.7645 & -0.1782 \\
\hline \multirow{2}{*}{$\begin{array}{l}\text { Greater personal income } \\
\text { (FIN3) }\end{array}$} & \multirow{2}{*}{-0.7641} & Yes & -5.0720 & 0.0000 & 0.1507 & -1.0605 & -0.4678 \\
\hline & & No & -5.4960 & 0.0000 & 0.1390 & -1.0383 & -0.4900 \\
\hline \multirow{2}{*}{ Financial security (FIN4) } & \multirow{2}{*}{-0.7953} & Yes & -5.1190 & 0.0000 & 0.1554 & -1.1010 & -0.4897 \\
\hline & & No & -6.0280 & 0.0000 & 0.1319 & -1.0552 & -0.5355 \\
\hline \multirow{2}{*}{ Build wealth (FIN5) } & \multirow{2}{*}{-0.5793} & Yes & -3.5290 & 0.0000 & 0.1642 & -0.9022 & -0.2563 \\
\hline & & No & -3.7510 & 0.0000 & 0.1544 & -0.8838 & -0.2747 \\
\hline \multirow{2}{*}{ Flexibility (IND1) } & \multirow{2}{*}{-0.4610} & Yes & -2.7310 & 0.0070 & 0.1688 & -0.7931 & -0.1288 \\
\hline & & No & -2.8890 & 0.0040 & 0.1596 & -0.7757 & -0.1462 \\
\hline \multirow{2}{*}{$\begin{array}{l}\text { Freedom for work methods } \\
\text { (IND2) }\end{array}$} & \multirow{2}{*}{-0.4336} & Yes & -2.9170 & 0.0040 & 0.1487 & -0.7260 & -0.1411 \\
\hline & & No & -2.9060 & 0.0040 & 0.1492 & -0.7281 & -0.1390 \\
\hline \multirow{2}{*}{$\begin{array}{l}\text { Follow technological } \\
\text { innovation(INOV2) }\end{array}$} & \multirow{2}{*}{-0.6275} & Yes & -4.0120 & 0.0000 & 0.1564 & -0.9351 & -0.3198 \\
\hline & & No & -4.0060 & 0.0000 & 0.1567 & -0.9367 & -0.3182 \\
\hline \multirow{2}{*}{$\begin{array}{l}\text { Many products ideas } \\
\text { (INOV3) }\end{array}$} & \multirow{2}{*}{-0.3421} & Yes & -2.2900 & 0.0230 & 0.1494 & -0.6359 & -0.0482 \\
\hline & & No & -2.2790 & 0.0240 & 0.1501 & -0.6385 & -0.0457 \\
\hline \multirow{2}{*}{ Market opportunity (INOV4) } & \multirow{2}{*}{-0.3660} & Yes & -3.2390 & 0.0010 & 0.1130 & -0.5882 & -0.1437 \\
\hline & & No & -3.0750 & 0.0020 & 0.1190 & -0.6011 & -0.1308 \\
\hline \multirow{2}{*}{ Family tradition (PA2) } & \multirow{2}{*}{-0.2822} & Yes & -2.5880 & 0.0100 & 0.1090 & -0.4967 & -0.0677 \\
\hline & & No & -3.1870 & 0.0020 & 0.0885 & -0.4565 & -0.1079 \\
\hline \multirow{2}{*}{ Follow examples (PA3) } & \multirow{2}{*}{-0.6513} & Yes & -4.2080 & 0.0000 & 0.1548 & -0.9558 & -0.3468 \\
\hline & & No & -4.4750 & 0.0000 & 0.1455 & -0.9384 & -0.3643 \\
\hline
\end{tabular}

Notes: Diff in Means is Mean(Leaders, N=92) - Mean(Other entrepreneurs, N=233). Equal variances indicates if the difference in means test assumes equal or unequal variances. Std. Error, t, Sig, Lower and Upper are the standard error of the difference in means, $t$ statistic of the test, $p$-value of the test, and the lower and upper

Page 12 of 23 
bounds of a $95 \%$ confidence interval for the difference in means, respectively. AR is self-realization, FIN is Financial Success, INOV is Innovation, PA is Roles and REC is Recognition.

This is the second-largest cluster. It has the largest proportions of entrepreneurs in the 35 to 42 years old range $(20 \%)$ and with startup experience $(15 \%)$. This indicates that this group has a large percentage of serial entrepreneurs. These people feel the need to lead and motivate others more than other entrepreneurs, and is their defining characteristic. Still within the Self-Realization factor, they do not see power as an important variable to enterprise. This may also be derived from their greater experience. Del Junco and Brás-dos-Santos (2009) document this characteristic for Italian entrepreneurs, who cite enjoyment as a motivation to start a business.

In the financial realm, this cluster's entrepreneurs exhibit lower expectations than the others in four out of the five variables. It can signal the fact that this cluster has older people, with more previous startup experience, the lower importance given to financial variables being a reflection of more maturity. After all, these people are more aware of the financial difficulties of running a startup, and may have better adjusted expectations regarding financial outcomes. This group exhibits a behavior different from Spanish, German and Italian entrepreneurs documented by Del Junco and Brás-dos-Santos (2009), and from Chinese entrepreneurs documented by Yueh (2009). Their more experienced and mature nature indicate that these entrepreneurs have lost the idea of enterprising because of status and financial return (Dubini 1989; Carsrud and Brännback 2011; Friedman and Aziz 2012).

All of the two independence variables exhibit lower means, showing the same pattern of contradicting previous results that show this factor as relevant for entrepreneurs (Del Junco and Brás-dos-Santos 2009). Here the same mechanism can be at play, with these experienced entrepreneurs having lower regard for independence than less experienced entrepreneurs. These leader entrepreneurs also rank innovation lower than others. They think that following technological trends, having many product ideas, and exploiting a market opportunity as less important than other entrepreneurs. Again, experience may be driving this result.

These entrepreneurs also do not seem concerned about role models. Two out of the three variables within this factor show lower means when compared to others. This contradicts findings in other settings, like Dubini (1989), Shane et al., (1996) and Bosma et al. (2012). These experienced people seem to worry less about keeping up family tradition and following examples.

This cluster groups entrepreneurs with high regard when it comes to leading and motivating others. They do it in detriment to other factors, like financial success, independence, innovation, and roles. The mechanism behind this pattern may be maturity, these entrepreneurs having already lived these experiences and focusing on the one thing they distilled from their past enterprises.

\subsubsection{Pessimistic Entrepreneurs}

The last cluster is denominated the Pessimistic Entrepreneurs. Table 8 shows a pattern of negative differences for all variables from all factors. Hence, this cluster is christened Pessimistic Entrepreneurs.

Table 8: Pessimistic cluster vs. other entrepreneurs - differences in means

\begin{tabular}{lcccccccc}
\hline \multicolumn{1}{c}{ Variables } & $\begin{array}{c}\text { Diff in } \\
\text { Means }\end{array}$ & $\begin{array}{c}\text { Equal } \\
\text { variances }\end{array}$ & $\begin{array}{c}\text { Std. } \\
\text { Error }\end{array}$ & t & Sig. & Lower & Upper \\
\hline \multirow{2}{*}{ Self-accomplishment (AR1) } & -1.0238 & Yes & 0.1417 & -7.2270 & 0.0000 & -1.3026 & -0.7451 \\
& & No & 0.1863 & -5.4950 & 0.0000 & -1.3955 & -0.6521 \\
New challenges (AR2) & \multirow{2}{*}{-0.9485} & Yes & 0.1365 & -6.9490 & 0.0000 & -1.2170 & -0.6799 \\
& & No & 0.1759 & -5.3930 & 0.0000 & -1.2992 & -0.5977 \\
Learn as a person (AR3) & \multirow{2}{*}{-1.1499} & Yes & 0.1302 & -8.8300 & 0.0000 & -1.4061 & -0.8937 \\
Lead and motivate others & & No & 0.1609 & -7.1450 & 0.0000 & -1.4707 & -0.8290 \\
(AR4) & -1.5237 & Yes & 0.1612 & -9.4550 & 0.0000 & -1.8407 & -1.2067 \\
& \multirow{2}{*}{ No } & 0.1739 & -8.7650 & 0.0000 & -1.8697 & -1.1777 \\
& -1.5151 & Yes & 0.1773 & -8.5450 & 0.0000 & -1.8639 & -1.1663
\end{tabular}

Page 13 of 23 


\begin{tabular}{|c|c|c|c|c|c|c|c|}
\hline $\begin{array}{l}\text { To have power to influence a } \\
\text { company (AR5) }\end{array}$ & & No & 0.1555 & -9.7440 & 0.0000 & -1.8235 & -1.2067 \\
\hline \multirow{2}{*}{ Financial success (FIN1) } & \multirow{2}{*}{-1.1262} & Yes & 0.1326 & -8.4940 & 0.0000 & -1.3870 & -0.8653 \\
\hline & & No & 0.1669 & -6.7480 & 0.0000 & -1.4589 & -0.7934 \\
\hline \multirow{2}{*}{$\begin{array}{l}\text { Financial independence } \\
\text { (FIN2) }\end{array}$} & \multirow{2}{*}{-1.5408} & Yes & 0.1588 & -9.7040 & 0.0000 & -1.8531 & -1.2284 \\
\hline & & No & 0.1604 & -9.6040 & 0.0000 & -1.8598 & -1.2218 \\
\hline \multirow{2}{*}{$\begin{array}{l}\text { Greater personal income } \\
\text { (FIN3) }\end{array}$} & \multirow{2}{*}{-1.3212} & Yes & 0.1675 & -7.8870 & 0.0000 & -1.6508 & -0.9916 \\
\hline & & No & 0.1638 & -8.0660 & 0.0000 & -1.6467 & -0.9957 \\
\hline \multirow{2}{*}{ Financial security (FIN4) } & \multirow{2}{*}{-0.7995} & Yes & 0.1835 & -4.3570 & 0.0000 & -1.1605 & -0.4385 \\
\hline & & No & 0.1438 & -5.5620 & 0.0000 & -1.0841 & -0.5150 \\
\hline \multirow{2}{*}{ Build wealth (FIN5) } & \multirow{2}{*}{-1.5043} & Yes & 0.1767 & -8.5140 & 0.0000 & -1.8519 & -1.1567 \\
\hline & & No & 0.1448 & -10.3930 & 0.0000 & -1.7911 & -1.2176 \\
\hline \multirow{2}{*}{ Flexibility (IND1) } & \multirow{2}{*}{-0.9613} & Yes & 0.1923 & -5.0000 & 0.0000 & -1.3396 & -0.5831 \\
\hline & & No & 0.2014 & -4.7740 & 0.0000 & -1.3619 & -0.5607 \\
\hline \multirow{2}{*}{$\begin{array}{l}\text { Freedom for work methods } \\
\text { (IND2) }\end{array}$} & \multirow{2}{*}{-0.8403} & Yes & 0.1697 & -4.9520 & 0.0000 & -1.1741 & -0.5065 \\
\hline & & No & 0.1929 & -4.3570 & 0.0000 & -1.2244 & -0.4562 \\
\hline \multirow{2}{*}{$\begin{array}{l}\text { Create and sell new products } \\
\text { (INOV1) }\end{array}$} & \multirow{2}{*}{-0.6444} & Yes & 0.1751 & -3.6800 & 0.0000 & -0.9889 & -0.2999 \\
\hline & & No & 0.2038 & -3.1620 & 0.0020 & -1.0504 & -0.2384 \\
\hline \multirow{2}{*}{$\begin{array}{l}\text { Follow technological } \\
\text { innovation(INOV2) }\end{array}$} & \multirow{2}{*}{-0.6149} & Yes & 0.1841 & -3.3400 & 0.0010 & -0.9771 & -0.2527 \\
\hline & & No & 0.1981 & -3.1040 & 0.0030 & -1.0091 & -0.2206 \\
\hline \multirow{2}{*}{$\begin{array}{l}\text { Many products ideas } \\
\text { (INOV3) }\end{array}$} & \multirow{2}{*}{-0.4502} & Yes & 0.1742 & -2.5850 & 0.0100 & -0.7929 & -0.1076 \\
\hline & & No & 0.1907 & -2.3600 & 0.0210 & -0.8299 & -0.0705 \\
\hline \multirow{2}{*}{ Market opportunity (INOV4) } & \multirow{2}{*}{-0.4342} & Yes & 0.1320 & -3.2900 & 0.0010 & -0.6939 & -0.1746 \\
\hline & & No & 0.1607 & -2.7030 & 0.0090 & -0.7545 & -0.1140 \\
\hline \multirow{2}{*}{ For children inherit (PA1) } & \multirow{2}{*}{-0.8546} & Yes & 0.1732 & -4.9350 & 0.0000 & -1.1953 & -0.5139 \\
\hline & & No & 0.1328 & -6.4370 & 0.0000 & -1.1173 & -0.5919 \\
\hline \multirow{2}{*}{ Family tradition (PA2) } & \multirow{2}{*}{-0.4698} & Yes & 0.1261 & -3.7270 & 0.0000 & -0.7178 & -0.2218 \\
\hline & & No & 0.0715 & -6.5730 & 0.0000 & -0.6105 & -0.3291 \\
\hline \multirow{2}{*}{ Follow examples (PA3) } & \multirow{2}{*}{-1.2409} & Yes & 0.1725 & -7.1950 & 0.0000 & -1.5802 & -0.9016 \\
\hline & & No & 0.1497 & -8.2900 & 0.0000 & -1.5377 & -0.9440 \\
\hline Importance in market - & & Yes & 0.1714 & -4.1440 & 0.0000 & -1.0472 & -0.3730 \\
\hline society (REC1) & -0 & No & 0.1945 & -3.6510 & 0.0000 & -1.0974 & -0.3227 \\
\hline Society's recognition & & Yes & 0.1745 & -7.2650 & 0.0000 & -1.6106 & -0.9242 \\
\hline (REC2) & - & No & 0.1581 & -8.0180 & 0.0000 & -1.5812 & -0.9537 \\
\hline & & Yes & 0.0892 & -3.4750 & 0.0010 & -0.4856 & -0.1345 \\
\hline $\mathrm{Fr}$ & -1 & No & 0.0558 & -5.5600 & 0.0000 & -0.4200 & -0.2001 \\
\hline
\end{tabular}

Notes: Diff in Means is Mean(Pessimistic, N=59) - Mean(Other entrepreneurs, N=266). Equal variances indicates if the difference in means test assumes equal or unequal variances. Std. Error, t, Sig, Lower and Upper are the standard error of the difference in means, $t$ statistic of the test, $\mathrm{p}$-value of the test, and the lower and upper bounds of a $95 \%$ confidence interval for the difference in means, respectively. AR is self-realization, FIN is Financial Success, INOV is Innovation, PA is Roles and REC is Recognition.

This is the smallest cluster, with only 59 respondents. It has the largest proportion of women, 11\%, highlighting a predominantly male setting. The cluster contains many young people from 25 to 28 years old $(35.59 \%)$, with a bachelor's degree $(54.23 \%)$, working in service and others (both with $27.11 \%$ ), with previous experience in other companies but without startup experience (47.45\%).

This cluster contradicts many of the existing literature on the reasons to enterprise. The lower scores in the Self-Realization factor show a pattern somewhat different from previous research. Roberts (1989) reports

Page 14 of 23 
that the median technical entrepreneur has a moderate need for achievement and power, and a thirst for new and bold challenges. Botsaris and Vamvaka (2016) report that for a sample of Greek entrepreneurs, selfrealization and challenge are strong predictors of entrepreneurial attitude. However, Carter et al (2003) report that entrepreneurs and non-entrepreneurs rate self-realization equally as a determinant of career choice.

As for the Financial factor, the lower scores, in a way, support the findings of Roberts (1989), which claims that technical entrepreneurs do not focus as much on financial success. Carter et al (2003) also provide evidence that entrepreneurs and non-entrepreneurs weight financial success equally as a determinant of their career choice. However, it contradicts results from Yueh (2009) and Del Junco and Brás-dos-Santos (2009), who document financial success and wealth accumulation as important reasons for starting a business. However, Dawson and Henley (2012) document that men and women think differently about financial success as a reason to enterprise, men focusing more on money than women.

Regarding Independence, previous research shows that autonomy is a strong predictor of entrepreneur attitude (Botsaris and Vamvaka 2016; Dawson and Henley 2012; Kirkley 2016; Del Junco and Brás-dosSantos 2009). This cluster, in turn, ranks this factor lower than others. There is indication that men and women value independence differently, though. Vliamos and Tzeremes (2012) show that for a Greek sample, level of independence is a significant factor for men, but not for women, in the entrepreneurial process. However, Dawson and Henley (2012) report that women cite independence as a motivation for entrepreneurship more frequently than men.

When it comes to Innovation, Kirkley (2016) reports creativity as a critical value to motivate entrepreneurial behavior. This cluster shows the opposite, showing some support for the findings of Carter et al (2003), in which entrepreneurs and non-entrepreneurs rate innovation equally as a reason for their career choices. As for roles, this group also supports Carter et al (2003) findings, that entrepreneurs think of roles as less important for their choice than non-entrepreneurs. Dawson and Henley (2012) also report joining family businesses as a relatively infrequent reason (around 6\% of respondents) to enterprise.

Finally, entrepreneurs from this cluster do not expect recognition as much as their counterparts. They differ from Turkish entrepreneurs, who frequently cite entrepreneurship as a career with high status (Friedman and Aziz 2012). However, they resemble entrepreneurs from Carter et al (2003), who rank recognition lower than non-entrepreneurs as a determinant of their career choice.

The pessimistic nature of this cluster may have to do with the relatively high proportion of women in it. There is evidence that men and women value factors differently (Dawson and Henley 2012; Vliamos and Tzeremes 2012; Maysami and Goby 1999). However, there is some evidence that culture may play a bigger role than gender (Costa Jr et al. 2001). Hence, an alternative explanation is that this cluster aggregates owners who are aware of the high failure rates of technological startups (Dubini 1989; Francis and Bessant 2005). Women may be simply more conscious of this fact, or the presence of more women may be just a coincidence.

\section{CONCLUSION}

This study identifies the profiles of technological entrepreneurs in Brazil, a large developing economy. It answers calls for more internationalization from Ferreira et al. (2016), which shows that extant research is heavily concentrated in the US, UK and Netherlands. It is also a step towards the separation of studies from advanced and developing countries, as advocated by Quatraro and Vivarelli (2015), who argue that different levels of development affect the entrepreneurial phenomenon. It uncovers four distinct groups of entrepreneurs. The first, financial success entrepreneurs, are concerned about financial outcomes of their startups. The new challenges group seeks self-realization, innovation, and independence by means of their 
enterprises. Leaders are driven by the will to lead and motivate others, relegating other factors. Finally, there are pessimistic entrepreneurs, who rank all reasons lower than other entrepreneurs.

As a result of the Ward's hierarchical clustering algorithm, the groups are reasonably well balanced in size. Financial success entrepreneurs are $24 \%$ of the sample, new challenges are $30 \%$, leaders comprise $28 \%$, and pessimistic are the remaining $18 \%$. This shows that even within the class of technological entrepreneurs, from a single country, there are sizeable groups with different factors regarding reasons to enterprise. Bjørnskov and Foss (2016) argue that, usually, is it assumed that there is homogeneity in responses to institutional and policy differences across the board, leading to measurement error. This classification emphasizes that this homogeneity does not hold, not even within the same industry in the same country. This may help conciliating conflicting results found on the entrepreneurial motivation literature (Shane 1996; Muller and Thomas 2001; Dvir et al. 2010; Barba-Sanchez and Atienza-Sahuquillo 2011), highlighting the importance of acknowledging that there are different entrepreneur profiles, with potentially different responses to the same stimuli.

Findings from this study can feed discussions about policy design to support entrepreneurship. Understanding the different motivations of different groups can generate more effective, directed policies, generating adequate levels of entrepreneurial activity, and maximizing the benefits of entrepreneurship (Vivarelli 2013; Bosma et al. 2012; Parker 2005; Mueller and Thomas 2001; Shane 1996). These results can also support the development of better assistance for nascent businesses, increasing the likelihood of survival, and amplifying the economic benefits of entrepreneurship (Chen and Elston 2013; Martín-Rojas et al. 2013; Vivarelli 2013; Shane 2009; Parker 2005; Krueger and Brazeal 1994). These groups also support Bjørnskov and Foss (2016) concern, that there is heterogeneity between entrepreneurs that must be taken into account, as they respond differently to different institutions and policies. These differences also indicate that these groups may also generate diverse relationships with partners and competitors, facilitating the matching between investors' and entrepreneurs' interests (Khosla 2012).

The literature has shown time and again how a healthy entrepreneurship environment is important for the overall economy (Bjørnskov and Foss 2016; Ferreira et al 2016; Galindo and Méndez 2014; Stephens et al. 2013). Some research has argued that part of such healthy environment involves incentivizing the "right" types of entrepreneurship, at adequate levels, or risk entrepreneurship not creating value or even destroying value (Vivarelli 2013; Shane 2009; Parker 2005). However, to be able to create targeted policies like this entangles knowing the entrepreneur, who is the main actor of the phenomenon (Gartner, 1990; Dvir et al., 2010). Clustering these entrepreneurs into a tractable number of groups is paramount, as a policy cannot be custom-designed to fit each and every person in every aspect. The four groups found in this study demonstrate the usefulness of such exercise, as it highlights the heterogeneity that exists even within a certain industry from a single country. This contribution is a first step in better understanding the motivations of entrepreneurs in developing economies.

A limitation of this research is the relatively restricted sample size. Furthermore, the sample is not probabilistic, constructed according to convenience. Consequently, results from this study must be interpreted with caution, with further investigation needed before making wider generalizations.

To address these issues, one suggestion is applying the same method in a broader sample, with more respondents. Another extension is to resort to qualitative methods with a more individual approach, to better understand the reasoning and sentiments of entrepreneurs. This study is restricted to technological entrepreneurs, and a natural derivation would be to repeat the procedure with nascent businesses of different types. A potentially fruitful avenue of research would be tracking these enterprises over time and measuring whether different entrepreneur profiles relate to metrics like survival rate, profitability, and social responsibility. 


\section{REFERENCES}

Autio, E., Keeley, R. H., Klofsten, M., Parker, G. G. C., \& Hay, M. (2001). Entrepreneurial intent among students in Scandinavia and in the USA. Enterprise and Innovation Management Studies, 2(2), 145-160.

Barba-Sanchez, V., \& Atienza-Sahuquillo, C. (2011). Reasons to create a new venture: A determinant of entrepreneurial profiles. African Journal of Business Management, 5(28), 11497-11504.

Baum, J. R., Locke, E. A., \& Smith, K. G. A multidimensional model of venture growth. Academy of Management Journal, 44.2 (2001): 292-303.

Birley, S., Westhead, P. (1994) A taxonomy of business start-up reasons and their impact on firm growth and size. Journal of Business Venturing, 9(1), 7-31, doi:10.1016/0883-9026(94)90024-8.

Bjørnskov, C. and Foss, N.J. (2016) Institutions, Entrepreneurship, and Economic Growth: What Do We Know and What Do We Still Need to Know? The Academy of Management Perspectives, 30(3), 292-315, doi: 10.5465/amp.2015.0135.

Bosma, N., Hessels, J., Schutjens, V., Praag, M. V., \& Verheul, I. (2012). Entrepreneurship and role models. Journal of Economic Psychology, 33(2), 410-424.

Botsaris, C. \& Vamvaka, V. (2016). Attitude Toward Entrepreneurship: Structure, Prediction from Behavioral Beliefs, and Relation to Entrepreneurial Intention. Journal of the Knowledge Economy, doi:10.1007/s13132-014-0227-2.

Brandstätter, H. (2011). Personality aspects of entrepreneurship: A look at five meta-analyses. Personality and Individual Differences, 51(3), 222-230, doi: 10.1016/j.paid.2010.07.007.

Buijs, J. (2008). Action planning for new product development projects. Creativity and Innovation Management, 17(4), 319-333.

Carayannis, E. G., Popescu, D., Sipp, C., \& Stewart, M. (2006). Technological learning for entrepreneurial development (TL4ED) in the knowledge economy (KE): case studies and lessons learned. Technovation, 26(4), 419-443.

Carsrud, A., \& Brännback, M. (2011). Entrepreneurial motivations: what do we still need to know? Journal of Small Business Management, 49(1), 9-26.

Carter, N. M., Gartner, W. B., \& Reynolds, P. D. (1996). Exploring start-up event sequences. Journal of Business Venturing, 11(3), 151-166.

Carter, N. M., Gartner, W. B., Shaver, K. G., \& Gatewood, E. J. (2003). The career reasons of nascent entrepreneurs. Journal of Business Venturing, 18(1), 13-39.

Chen, S. C., \& Elston, J. A. (2013). Entrepreneurial motives and characteristics: An analysis of small restaurant owners. International Journal of Hospitality Management, 35, 294-305.

Collins, C. J., Hanges, P.J., and Locke E. A. (2004). The Relationship of Achievement Motivation to Entrepreneurial Behavior: A Meta-Analysis. Human Performance, 17(1) 95-117, doi: 10.1207/S15327043HUP1701_5.

Costa Jr., P., Terracciano, A., McCrae, R. R. (2001). Gender differences in personality traits across cultures: Robust and surprising findings. Journal of Personality and Social Psychology, 81(2), 322-331.

Cowling, M. (2000). Are entrepreneurs different across countries? Applied Economics Letters, 7(12), 785789. 
Dawson, C and Henley, A. (2012). "Push" versus "pull" entrepreneurship: an ambiguous distinction? International Journal of Entrepreneurial Behavior \& Research, 18(6), 697-719.

Del Junco, J. G., \& Brás-dos-Santos, J. M. (2009). How different are the entrepreneurs in the European Union internal market? - An exploratory cross-cultural analysis of German, Italian and Spanish entrepreneurs. Journal of International Entrepreneurship, 7(2), 135-162.

Dubini, P. (1989). The influence of motivations and environment on business start-ups: Some hints for public policies. Journal of Business Venturing, 4(1), 11-26.

Dvir, D., Sadeh, A., \& Malach-Pines, A. (2010). The fit between entrepreneurs' personalities and the profile of the ventures they manage and business success: An exploratory study. The Journal of High Technology Management Research, 21(1), 43-51, doi: 10.1016/j.hitech.2010.02.006.

Ferreira, J.J.M., Ferreira, F.A.F., Fernandes, C.I.M.A.S., Jalali M.S., Raposo, M.L., Marques, C.S. (2016). What do we [not] know about technology entrepreneurship research? International Entrepreneurship and Management Journal, 12(3), 713-733, doi:10.1007/s11365-015-0359-2.

Francis, D., \& Bessant, J. (2005). Targeting innovation and implications for capability development. Technovation, 25(3), 171-183.

Friedman, B. A., \& Aziz, N. (2012). Turkey and the United States: Entrepreneurship Activity, Motives, Aspirations, \& Perceptions. International Journal of Business and Social Science, 3(3), 96-107.

Galindo, M. A., Méndez, M. T. (2014). Entrepreneurship, economic growth, and innovation: Are feedback effects at work? Journal of Business Research, 67(5), Pages 825-829.

Gartner, W. B. (1990) What are we talking about when we talk about entrepreneurship? Journal of Business Venturing, 5(1), 15-28.

Gupta, V., \& Fernandez, C. (2009). Cross-Cultural Similarities and Differences in Characteristics Attributed to Entrepreneurs A Three-Nation Study. Journal of Leadership and Organizational Studies, 15(3), 304-318.

Hair, J.F.; Babin, B.J.; Money, A.H. and Samouel, P. (2003) Essentials of Business Research Methods. New York, NY: Wiley.

Hayton, J. C., Cholakova, M. (2012). The role of affect in the creation and intentional pursuit of entrepreneurial ideas. Entrepreneurship Theory and Practice, 36(1), 41-68.

Jayawarna, D., Rouse, J., Kitching, J. (2013). Entrepreneur motivations and life course. International Small Business Journal, 31(1), 34-56, doi: 10.1177/0266242611401444.

Jeng, L. A., Wells, P. C. (2000). The determinants of venture capital funding: evidence across countries. Journal of Corporate Finance, 6(3), 241-289, doi: 10.1016/S0929-1199(00)00003-1.

Khosla, V. (2012). Maintain the Silicon Valley Vision. Available at https://bits.blogs.nytimes.com/2012/07/13/khosla-the-silicon-valley-vision. Accessed Jan 27 $7^{\text {th }}, 2017$.

King, R. G., Levine, R. (1993). Finance, entrepreneurship and growth. Journal of Monetary Economics, 32(3), 513-542.

Kirkley, W. W. (2016). Entrepreneurial behaviour: the role of values. International Journal of Entrepreneurial Behavior \& Research, 22(3), 290 - 328.

Koellinger, P., Minniti, M., Schade, C. (2007). "I think I can, I think I can": Overconfidence and entrepreneurial behavior. Journal of Economic Psychology, 28(4), 502-527.

Krueger, N. F., \& Brazeal, D. V. (1994). Entrepreneurial potential and potential entrepreneurs. Entrepreneurship Theory and Practice, 18, 91-91.

Liao, J., Welsch, H. and Tan, W. L. (2005). Venture gestation paths of nascent entrepreneurs: Exploring the temporal patterns. The Journal of High Technology Management Research, 16(1), 1-22.

Page 18 of 23 
Martín-Rojas, R., García-Morales, V. J.,, Bolívar-Ramos, M. T. (2013). Influence of technological support, skills and competencies, and learning on corporate entrepreneurship in European technology firms. Technovation, 33(12), 417-430.

Maslow, A. H. (1943). A theory of human motivation. Psychological Review. 50(4), 370-396.

Maysami, R. C and Goby, V. P. (1999). Journal of Small Business Management, 37(2), 96-105.

Mueller, S. L. and Thomas, A. S. (2001). Culture and entrepreneurial potential: A nine country study of locus of control and innovativeness. Journal of Business Venturing, 16(1), 51-75.

Owens, K. S., Kirwan, J. R., Lounsbury, J. W., Levy, J. J., and Gibson, L. W. (2013) Personality correlates of self-employed small business owners' success. Work, 45(1), 73-85, doi: 10.3233/WOR-121536.

Parker, S. C. (2005). The Economics of Entrepreneurship: What We Know and What We Don't. Foundations and Trends in Entrepreneurship, 1(1), 1-54, doi:10.1561/0300000001.

Quatraro, F. and Vivarelli, M. (2015). Drivers of Entrepreneurship and Post-entry Performance of Newborn Firms in Developing Countries. World Bank Research Observer, 30(2), 277-305, doi: 10.1093/wbro/lku012.

Roberts, E. B. (1989). The personality and motivations of technological entrepreneurs. Journal of Engineering and Technology Management, 6(1), 5-23.

Shane, S. (1996). Explaining variation in rates of entrepreneurship in the United States: 1899-1988. Journal of Management, 22(5), 747-781.

Shane, S. (2009). Why encouraging more people to become entrepreneurs is bad public policy. Small Business Economics, 33(2), 141-149, doi:10.1007/s11187-009-9215-5.

Shane, S., Kolvereid, L., Westhead, P. (1991). An exploratory examination of the reasons leading to new firm formation across country and gender. Journal of Business Venturing, 6(6), 431-446, doi: 10.1016/0883-9026(91)90029-D.

Shane, S., Locke, E. A., \& Collins, C. J. (2003). Entrepreneurial motivation. Human Resource Management Review, 13(2), 257-279.

Shaver, K. G., Gartner, W. B., Gatewood, E. J., Crosby, E., Bakalarova, K. (2001). Attributions about entrepreneurship: A framework and process for analyzing reasons for starting a business. Entrepreneurship Theory and Practice, 26, 5-32.

Stephens, H. M., Partridge, M. D. and Faggian, A. (2013) Innovation, Entrepreneurship and Economic Growth in Lagging Regions. Journal of Regional Science, doi:10.1111/jors.12019.

Taormina, R. J., Lao, S. K. (2007). Measuring Chinese entrepreneurial motivation: personality and environmental influences. International Journal of Entrepreneurial Behavior \& Research, 13(4), 200 221, doi: 10.1108/13552550710759997.

Vivarelli, M. (2013). Is entrepreneurship necessarily good? Microeconomic evidence from developed and developing countries. Industrial and Corporate Change, 22 (6), 1453-1495. doi: 10.1093/icc/dtt005.

Vliamos, S.J. \& Tzeremes, N.G. (2012). Factors Influencing Entrepreneurial Process and Firm Start-Ups: Evidence from Central Greece. Journal of the Knowledge Economy, doi:10.1007/s13132-011-0043-x.

Winarick, K. (2010) Thoughts on greed and envy. The American Journal of Psychoanalysis, doi: 10.1057/ajp.2010.23.

Yueh, L. (2009). China's entrepreneurs. World Development, 37(4), 778-786. 


\section{APPENDIX}

Table 9: Financial Success cluster

\begin{tabular}{|c|c|c|c|c|c|}
\hline CL1 & & $\mathrm{N}$ & Mean & $\begin{array}{l}\text { Std. } \\
\text { Deviation }\end{array}$ & $\begin{array}{l}\text { Std. Error } \\
\text { Mean }\end{array}$ \\
\hline \multirow{2}{*}{ To have power to influence a company (AR5) } & CL1 & 78 & 3.7179 & 1.2577 & 0.1424 \\
\hline & Others & 247 & 3.0445 & 1.3563 & 0.0863 \\
\hline \multirow{2}{*}{ Financial success (FIN1) } & CL1 & 78 & 4.2949 & 0.7913 & 0.0896 \\
\hline & Others & 247 & 3.6478 & 1.0327 & 0.0657 \\
\hline \multirow{2}{*}{ Financial independence (FIN2) } & CL1 & 78 & 4.3333 & 0.8925 & 0.1011 \\
\hline & Others & 247 & 3.3239 & 1.2528 & 0.0797 \\
\hline \multirow{2}{*}{ Greater personal income (FIN3) } & CL1 & 78 & 4.1282 & 0.8880 & 0.1006 \\
\hline & Others & 247 & 2.9069 & 1.2311 & 0.0783 \\
\hline \multirow{2}{*}{ Financial security (FIN4) } & CL1 & 78 & 3.6667 & 1.1358 & 0.1286 \\
\hline & Others & 247 & 1.8664 & 1.0371 & 0.0660 \\
\hline \multirow{2}{*}{ Build wealth (FIN5) } & CL1 & 78 & 4.1154 & 0.9532 & 0.1079 \\
\hline & Others & 247 & 2.5506 & 1.2447 & 0.0792 \\
\hline \multirow{2}{*}{ Market opportunity (INOV4) } & CL1 & 78 & 4.6026 & 0.7786 & 0.0882 \\
\hline & Others & 247 & 4.2551 & 0.9605 & 0.0611 \\
\hline \multirow{2}{*}{ For children inherit (PA1) } & CL1 & 78 & 3.0513 & 1.3280 & 0.1504 \\
\hline & Others & 247 & 1.7409 & 1.0387 & 0.0661 \\
\hline \multirow{2}{*}{ Family tradition (PA2) } & CL1 & 78 & 1.9487 & 1.1941 & 0.1352 \\
\hline & Others & 247 & 1.2955 & 0.7083 & 0.0451 \\
\hline \multirow{2}{*}{ Follow examples (PA3) } & CL1 & 78 & 3.2308 & 1.2371 & 0.1401 \\
\hline & Others & 247 & 2.7692 & 1.2876 & 0.0819 \\
\hline \multirow{2}{*}{ Friend's respect (REC3) } & CL1 & 78 & 1.5128 & 0.7686 & 0.0870 \\
\hline & Others & 247 & 1.2389 & 0.5664 & 0.0360 \\
\hline
\end{tabular}

Table 10: New Challenges cluster

\begin{tabular}{llllll}
\hline CL2 & & $\mathrm{N}$ & Mean & Std. Deviation & Std. Error Mean \\
\hline \multirow{2}{*}{ Self-realization (AR1) } & & & & & \\
& CL2 & 96 & 4.5417 & 0.7096 & 0.0724 \\
\hline \multirow{2}{*}{ New challenges (AR2) } & Others & 229 & 4.0000 & 1.1394 & 0.0753 \\
\hline \multirow{2}{*}{ Learn as a person (AR3) } & CL2 & 96 & 4.7188 & 0.5564 & 0.0568 \\
& Others & 229 & 3.9825 & 1.0840 & 0.0716 \\
\hline \multirow{2}{*}{ Lead and motivate others (AR4) } & CL2 & 96 & 4.7188 & 0.5750 & 0.0587 \\
\hline To have power to influence a company(AR5) & CL2 & 96 & 3.9479 & 0.9986 & 0.0708 \\
\hline
\end{tabular}

Page 20 of 23 


\begin{tabular}{|c|c|c|c|c|c|}
\hline & Others & 229 & 2.8952 & 1.3757 & 0.0909 \\
\hline \multirow{2}{*}{ Financial success(FIN1) } & CL2 & 96 & 4.0729 & 0.8110 & 0.0828 \\
\hline & Others & 229 & 3.6900 & 1.0740 & 0.0710 \\
\hline \multirow{2}{*}{ Financial independence(FIN2) } & CL2 & 96 & 4.0417 & 0.8816 & 0.0900 \\
\hline & Others & 229 & 3.3668 & 1.3298 & 0.0879 \\
\hline \multirow{2}{*}{ Greater personal income(FIN3) } & CL2 & 96 & 3.6354 & 1.0374 & 0.1059 \\
\hline & Others & 229 & 3.0175 & 1.3144 & 0.0869 \\
\hline \multirow{2}{*}{ Flexibility(IND1) } & CL2 & 96 & 3.9792 & 1.1330 & 0.1156 \\
\hline & Others & 229 & 3.1048 & 1.4010 & 0.0926 \\
\hline \multirow{2}{*}{ Freedom for work methods(IND2) } & CL2 & 96 & 4.3125 & 0.7006 & 0.0715 \\
\hline & Others & 229 & 3.3537 & 1.2814 & 0.0847 \\
\hline \multirow{2}{*}{ Create and sell products (INOV1) } & CL2 & 96 & 4.0833 & 1.1394 & 0.1163 \\
\hline & Others & 229 & 3.5590 & 1.2504 & 0.0826 \\
\hline \multirow{2}{*}{ Follow technological innovation (INOV2) } & CL2 & 96 & 3.9792 & 0.9945 & 0.1015 \\
\hline & Others & 229 & 3.1354 & 1.3325 & 0.0881 \\
\hline \multirow{2}{*}{ Many products ideas (INOV3) } & CL2 & 96 & 4.2083 & 1.0752 & 0.1097 \\
\hline & Others & 229 & 3.6900 & 1.2478 & 0.0825 \\
\hline \multirow{2}{*}{ Market opportunity(INOV4) } & CL2 & 96 & 4.5938 & 0.6420 & 0.0655 \\
\hline & Others & 229 & 4.2314 & 1.0103 & 0.0668 \\
\hline \multirow{2}{*}{ For children inherit (PA1) } & CL2 & 96 & 1.8542 & 0.9839 & 0.1004 \\
\hline & Others & 229 & 2.1397 & 1.3337 & 0.0881 \\
\hline \multirow{2}{*}{ Follow examples (PA3) } & CL2 & 96 & 3.6667 & 1.0122 & 0.1033 \\
\hline & Others & 229 & 2.5502 & 1.2507 & 0.0827 \\
\hline \multirow{2}{*}{ Importance in market-society (REC1) } & CL2 & 96 & 4.1354 & 1.0323 & 0.1054 \\
\hline & Others & 229 & 3.6856 & 1.2694 & 0.0839 \\
\hline \multirow{2}{*}{ Society's acknoledge (REC2) } & CL2 & 96 & 3.2500 & 1.1698 & 0.1194 \\
\hline & Others & 229 & 2.5633 & 1.3084 & 0.0865 \\
\hline
\end{tabular}

Table 11: Leaders cluster

\begin{tabular}{|c|c|c|c|c|c|}
\hline CL3 & & $\mathrm{N}$ & Mean & $\begin{array}{l}\text { Std. } \\
\text { Deviation }\end{array}$ & $\begin{array}{l}\text { Std. Error } \\
\text { Mean }\end{array}$ \\
\hline \multirow{2}{*}{ Lead and motivate others (AR4) } & CL3 & 92 & 3.935 & 0.91152 & 0.09503 \\
\hline & Others & 233 & 3.519 & 1.36167 & 0.08921 \\
\hline \multirow{2}{*}{ To have power to influence a company (AR5) } & CL3 & 92 & 2.794 & 1.2539 & 0.13073 \\
\hline & Others & 233 & 3.369 & 1.37128 & 0.08984 \\
\hline \multirow{2}{*}{ Financial independence (FIN2) } & CL3 & 92 & 3.228 & 1.18696 & 0.12375 \\
\hline & Others & 233 & 3.7 & 1.25425 & 0.08217 \\
\hline \multirow{2}{*}{ Greater personal income (FIN3) } & CL3 & 92 & 2.652 & 1.06322 & 0.11085 \\
\hline & Others & 233 & 3.416 & 1.28086 & 0.08391 \\
\hline \multirow{2}{*}{ Financial security (FIN4) } & CL3 & 92 & 1.728 & 0.92704 & 0.09665 \\
\hline & Others & 233 & 2.524 & 1.37107 & 0.08982 \\
\hline Build wealth (FIN5) & CL3 & 92 & 2.511 & 1.19977 & 0.12508 \\
\hline
\end{tabular}

Page 21 of 23 


\begin{tabular}{llllll} 
& Others & 233 & 3.09 & 1.38201 & 0.09054 \\
\hline \multirow{2}{*}{ Flexibility (IND1) } & CL3 & 92 & 3.033 & 1.24434 & 0.12973 \\
\hline \multirow{2}{*}{ Freedom for work methods (IND2) } & Others & 233 & 3.494 & 1.41762 & 0.09287 \\
\hline \multirow{2}{*}{ Follow technological innovation(INOV2) } & CL3 & 92 & 3.326 & 1.21446 & 0.12662 \\
& Others & 233 & 3.76 & 1.20441 & 0.0789 \\
\hline \multirow{2}{*}{ Many products ideas (INOV3) } & CL3 & 92 & 2.935 & 1.27361 & 0.13278 \\
\hline \multirow{2}{*}{ Market opportunity (INOV4) } & Others & 233 & 3.562 & 1.26856 & 0.08311 \\
\hline \multirow{2}{*}{ Family tradition (PA2) } & CL3 & 92 & 3.598 & 1.22304 & 0.12751 \\
& Others & 233 & 3.94 & 1.20909 & 0.07921 \\
\hline \multirow{2}{*}{ Follow examples (PA3) } & CL3 & 92 & 4.076 & 0.99707 & 0.10395 \\
\hline
\end{tabular}

Table 12: Pessimistic cluster

\begin{tabular}{|c|c|c|c|c|c|}
\hline CL4 & & $\mathrm{N}$ & Mean & Std. Deviation & Std. Error Mean \\
\hline \multirow[t]{2}{*}{ Self-accomplishment (AR1) } & CL4 & 59 & 3.322 & 1.37013 & 0.17838 \\
\hline & Others & 266 & 4.346 & 0.87778 & 0.05382 \\
\hline \multirow[t]{2}{*}{ New challenges (AR2) } & CL4 & 59 & 3.424 & 1.28926 & 0.16785 \\
\hline & Others & 266 & 4.372 & 0.85595 & 0.05248 \\
\hline \multirow[t]{2}{*}{ Learn as a person (AR3) } & CL4 & 59 & 3.271 & 1.17195 & 0.15257 \\
\hline & Others & 266 & 4.421 & 0.83518 & 0.05121 \\
\hline \multirow[t]{2}{*}{ Lead and motivate others (AR4) } & CL4 & 59 & 2.39 & 1.232 & 0.16039 \\
\hline & Others & 266 & 3.914 & 1.09374 & 0.06706 \\
\hline \multirow[t]{2}{*}{ To have power to influence a company (AR5) } & CL4 & 59 & 1.966 & 1.03334 & 0.13453 \\
\hline & Others & 266 & 3.481 & 1.27147 & 0.07796 \\
\hline \multirow[t]{2}{*}{ Financial success (FIN1) } & CL4 & 59 & 2.881 & 1.21889 & 0.15869 \\
\hline & Others & 266 & 4.008 & 0.84225 & 0.05164 \\
\hline \multirow[t]{2}{*}{ Financial independence (FIN2) } & CL4 & 59 & 2.305 & 1.1181 & 0.14556 \\
\hline & Others & 266 & 3.846 & 1.10005 & 0.06745 \\
\hline \multirow[t]{2}{*}{ Greater personal income (FIN3) } & CL4 & 59 & 2.119 & 1.13083 & 0.14722 \\
\hline & Others & 266 & 3.44 & 1.17126 & 0.07181 \\
\hline \multirow[t]{2}{*}{ Financial security (FIN4) } & CL4 & 59 & 1.644 & 0.90521 & 0.11785 \\
\hline & Others & 266 & 2.444 & 1.34256 & 0.08232 \\
\hline \multirow[t]{2}{*}{ Build wealth (FIN5) } & CL4 & 59 & 1.695 & 0.93319 & 0.12149 \\
\hline & Others & 266 & 3.199 & 1.28333 & 0.07869 \\
\hline \multirow[t]{2}{*}{ Flexibility (IND1) } & CL4 & 59 & 2.576 & 1.41669 & 0.18444 \\
\hline & Others & 266 & 3.538 & 1.31769 & 0.08079 \\
\hline \multirow[t]{2}{*}{ Freedom for work methods (IND2) } & CL4 & 59 & 2.949 & 1.38245 & 0.17998 \\
\hline & Others & 266 & 3.79 & 1.12972 & 0.06927 \\
\hline
\end{tabular}

Page 22 of 23 


\begin{tabular}{llllll} 
Create and sell new products (INOV1) & CL4 & 59 & 3.186 & 1.46775 & 0.19109 \\
& Others & 266 & 3.831 & 1.15479 & 0.0708 \\
\hline Follow technological innovation (INOV2) & CL4 & 59 & 2.881 & 1.40301 & 0.18266 \\
& Others & 266 & 3.496 & 1.25065 & 0.07668 \\
\hline Many products ideas (INOV3) & CL4 & 59 & 3.475 & 1.35641 & 0.17659 \\
& Others & 266 & 3.925 & 1.17601 & 0.07211 \\
\hline Market opportunity (INOV4) & CL4 & 59 & 3.983 & 1.16695 & 0.15192 \\
& Others & 266 & 4.417 & 0.8527 & 0.05228 \\
\hline For children inherit (PA1) & CL4 & 59 & 1.356 & 0.82551 & 0.10747 \\
& Others & 266 & 2.211 & 1.27118 & 0.07794 \\
\hline Family tradition (PA2) & CL4 & 59 & 1.068 & 0.31428 & 0.04092 \\
& Others & 266 & 1.538 & 0.95586 & 0.05861 \\
\hline Follow examples (PA3) & CL4 & 59 & 1.864 & 0.9906 & 0.12897 \\
& Others & 266 & 3.105 & 1.23937 & 0.07599 \\
\hline Importance in market -society (REC1) & CL4 & 59 & 3.237 & 1.39382 & 0.18146 \\
& Others & 266 & 3.947 & 1.14144 & 0.06999 \\
\hline Society's recognition (REC2) & CL4 & 59 & 1.729 & 1.064 & 0.13852 \\
\hline Friend's respect (REC3) & Others & 266 & 2.996 & 1.24233 & 0.07617 \\
\hline & CL4 & 59 & 1.051 & 0.2891 & 0.03764 \\
& Others & 266 & 1.361 & 0.67111 & 0.04115 \\
\hline & & & & & \\
\hline & & & & & \\
& & & &
\end{tabular}

